\title{
Transport of regional pollutants through a remote trans-Himalayan valley in Nepal
}

\author{
Shradda Dhungel ${ }^{1}$, Bhogendra Kathayat ${ }^{2}$, Khadak Mahata ${ }^{3}$, and Arnico Panday ${ }^{1,4}$ \\ ${ }^{1}$ Department of Environmental Sciences, University of Virginia, Charlottesville, VA 22904, USA \\ ${ }^{2}$ Nepal Wireless, Shanti Marg, Pokhara, 33700, Nepal \\ ${ }^{3}$ Institute for Advanced Sustainability Studies, 14467 Potsdam, Germany \\ ${ }^{4}$ International Center for Integrated Mountain Development, Khulmaltar, Kathmandu, 44700, Nepal
}

Correspondence: Shradda Dhungel (shradda@virginia.edu)

Received: 16 September 2016 - Discussion started: 8 November 2016

Revised: 18 November 2017 - Accepted: 20 December 2017 - Published: 30 January 2018

\begin{abstract}
Anthropogenic emissions from the combustion of fossil fuels and biomass in Asia have increased in recent years. High concentrations of reactive trace gases and lightabsorbing and light-scattering particles from these sources form persistent haze layers, also known as atmospheric brown clouds, over the Indo-Gangetic plains (IGP) from December through early June. Models and satellite imagery suggest that strong wind systems within deep Himalayan valleys are major pathways by which pollutants from the IGP are transported to the higher Himalaya. However, observational evidence of the transport of polluted air masses through Himalayan valleys has been lacking to date. To evaluate this pathway, we measured black carbon (BC), ozone $\left(\mathrm{O}_{3}\right)$, and associated meteorological conditions within the Kali Gandaki Valley (KGV), Nepal, from January 2013 to July 2015. $\mathrm{BC}$ and $\mathrm{O}_{3}$ varied over both diurnal and seasonal cycles. Relative to nighttime, mean $\mathrm{BC}$ and $\mathrm{O}_{3}$ concentrations within the valley were higher during daytime when the up-valley flow (average velocity of $17 \mathrm{~m} \mathrm{~s}^{-1}$ ) dominated. BC and $\mathrm{O}_{3}$ concentrations also varied seasonally with minima during the monsoon season (July to September). Concentrations of both species subsequently increased post-monsoon and peaked during March to May. Average concentrations for $\mathrm{O}_{3}$ during the seasonally representative months of April, August, and November were 41.7, 24.5, and 29.4 ppbv, respectively, while the corresponding $\mathrm{BC}$ concentrations were $1.17,0.24$, and $1.01 \mu \mathrm{g} \mathrm{m}^{-3}$, respectively. Up-valley fluxes of $\mathrm{BC}$ were significantly greater than down-valley fluxes during all seasons. In addition, frequent episodes of BC concentrations 2-3 times higher than average persisted from several
\end{abstract}

days to a week during non-monsoon months. Our observations of increases in $\mathrm{BC}$ concentration and fluxes in the valley, particularly during pre-monsoon, provide evidence that trans-Himalayan valleys are important conduits for transport of pollutants from the IGP to the higher Himalaya.

\section{Introduction}

Persistent atmospheric haze, often referred to as atmospheric brown cloud (ABC) (Ramanathan and Crutzen, 2003), affects broad geographic regions including the Indo-Gangetic plains (IGP) in southern Asia (Ramanathan and Carmichael, 2008), eastern China (Ma et al., 2010), southeast Asia (Engling and Gelencser, 2010), sub-Saharan Africa (Piketh et al., 1999), Mexico (Vasilyev et al., 1995), and Brazil (Kaufman et al., 1998). In southern Asia, the haze covers extensive areas particularly during the period of mid-November to midJune preceding the summer monsoon season. Major combustion sources - including the anthropogenic burning of agricultural waste, garbage, biofuel, and fossil fuels as well as wildfires - emit volatile and particulate-phase compounds to the atmosphere that contain oxidized and reduced forms of sulfur, nitrogen, and organic carbon (OC) together with elemental (black) carbon (BC) and other species. These emissions are intermixed and chemically interact with mechanically produced aerosols (e.g., sea salt and mineral dust). Important secondary pollutants such as ozone $\left(\mathrm{O}_{3}\right)$ also form from photochemical reactions involving nitrogen oxides. Together, this mixture of atmospheric species constitutes the 
$\mathrm{ABC}$ or brown haze over southern Asia (Ramanathan et al., 2005; Gustafsson et al., 2009). These optically thick layers include high concentrations of light-absorbing and lightscattering particles (Menon et al., 2002) that modulate radiative transfer. Light-absorbing aerosols (primarily BC and crustal dust) contribute to atmospheric warming, while lightscattering aerosols (primarily $\mathrm{S}-, \mathrm{N}-$, and $\mathrm{OC}$-dominated particles) drive cooling at the surface. The combined effects of light-absorbing and light-scattering aerosols from anthropogenic sources serve to reduce UV and visible wavelength radiation at the surface (i.e., surface forcing), increase tropospheric warming (i.e., atmospheric forcing), and change the net top of the atmosphere solar flux (i.e., top-of-theatmosphere forcing) (Andreae and Crutzen, 1997; Kaufman et al., 2002; Ramanathan et al., 2005). Light-absorbing anthropogenic pollutants like BC also significantly influence global warming, in terms of direct radiative forcing (Jacobson, 2001; Bond et al., 2013), and regional influences from such pollutants close to sources are greater than those on the global scale (Ramanathan et al., 2007b).

The elevated concentrations of aerosols in the anti-cyclone have also been shown to weaken circulation patterns and reduce total monsoon precipitation over southern India (Ramanathan et al., 2005; Fadnavis et al., 2013) while intensifying the monsoon over the foothills of the Himalaya (Lau et al., 2006). In addition to warming the atmosphere, the rising concentrations of $\mathrm{BC}$ and $\mathrm{O}_{3}$ over southern Asia (e.g., Ramanathan and Carmichael, 2008) have detrimental impacts on human health. Recent work has shown that elevated levels of these two key pollutants can compromise cardiopulmonary and respiratory health (Krupnick et al., 1990; Janssen et al., 2011). In addition, $\mathrm{O}_{3}$ is a leading pollutant contributing to biodiversity loss (Royal Society, 2008) as well as declines in crop yields (Auffhammer et al., 2006).

Haze over the IGP often reaches heights of more than $3 \mathrm{~km}$ a.s.l. via convection and advection, and the Himalaya range forms a $2500 \mathrm{~km}$ long, $8 \mathrm{~km}$ high complex topographic barrier along the northern edge of the IGP (Singh et al., 2004; Dey and Di Girolamo, 2010; Gautam et al., 2011; Lüthi et al., 2015). Numerous studies have investigated the transport of pollutants from the IGP to the Himalayan foothills, the immediate source region for potential transport to the Tibetan Plateau (TP) (Pant et al., 2006; Dumka et al., 2008; Komppula et al., 2009; Hyvärinen et al., 2009; Ram et al., 2010; Brun et al., 2011; Gautam et al., 2011; Srivastava et al., 2012). Further, a suite of studies involving satellite imagery (Ramanathan et al., 2007a; Brun et al., 2011), back trajectories (Lu et al., 2011), model calculations (Kopacz et al., 2011; Zhang et al., 2015), ice core analyses (Lee et al., 2008; Kang et al., 2010), and measurements in the higher Himalaya (Bonasoni et al., 2010; Chen et al., 2017) strongly suggest that pollutants are efficiently transported from the IGP to the higher Himalaya and onto the Tibetan Plateau, especially during spring prior to the monsoon. This transport north of the Himalayas is potentially concerning as the TP plays a vi- tal role in regulating the regional climate due to its effect on the Asian summer monsoon (ASM) and the hydrologic cycle. In the TP, light-absorbing aerosols may not only serve warm the atmosphere but - when deposited onto snow and ice surfaces - may also decrease albedo and thereby substantially increase the melting rates of snow and glaciers (Kang et al., 2010). Indeed, model simulations (Qian et al., 2011) have shown that these light-absorbing aerosols change the surface radiative flux in the higher Himalaya and the TP by 5 to $25 \mathrm{~W} \mathrm{~m}^{-2}$ during the pre-monsoon months of April and May. The interrelated perturbations of the $\mathrm{ABC}$ on radiative transfer, air quality, the hydrologic cycle, and crop yields have important long-term implications for human health, food security, and economic activity over southern Asia. However, to date, there has been little observational research to directly demonstrate the role of mountain valleys in the transport of air pollutants from the IGP and the Himalayan foothills to higher elevations within and north of the Himalayan range.

In other studied mountain ranges, it is well known that flow patterns carry polluted air masses up valleys to higher elevations by providing a path of least resistance between tall mountains. In the European Alps, prevailing wind systems in the mountain river valleys funnel polluted air from peripheral source regions to high elevations in a phenomenon known as "alpine pumping" (Weissmann et al., 2005). Under fair-weather conditions during daytime, the upslope winds are capable of transporting significant pollutants and moisture into the free troposphere (Henne et al., 2004). Relative to air over plains, the air within the valley heats and cools more quickly (Steinacker, 1984). The resultant differences in temperature create gradients in pressure and density, which in turn drive the transport of air from the plains to higher elevations during the daytime (Reiter and Tang, 1984; Whiteman and Bian, 1998; Egger et al., 2000). Such direct evidence of a Himalayan mountain valley wind system and its role in pollution transport has been observed at 5079 ma.s.l., particularly during non-monsoon seasons, in the Khumbu valley in the eastern Himalaya (Bonasoni et al., 2010). However, the transport patterns of pollutants at the habitable midaltitudes within a trans-Himalayan valley have yet to be observed. Here we present 2.5 years of measurements of BC, $\mathrm{O}_{3}$, and associated meteorological data from one of the deepest trans-Himalayan valleys, the Kali Gandaki Valley (KGV). We examine seasonal and diurnal patterns of $\mathrm{BC}$ and $\mathrm{O}_{3}$, investigate potential episodes of enhanced pollution transport up-valley, and make a preliminary estimate of BC mass transport. In doing so, we seek to provide the first observational evidence of trans-Himalayan valleys acting as conduits for pollution transport from the IGP to the higher Himalaya. 


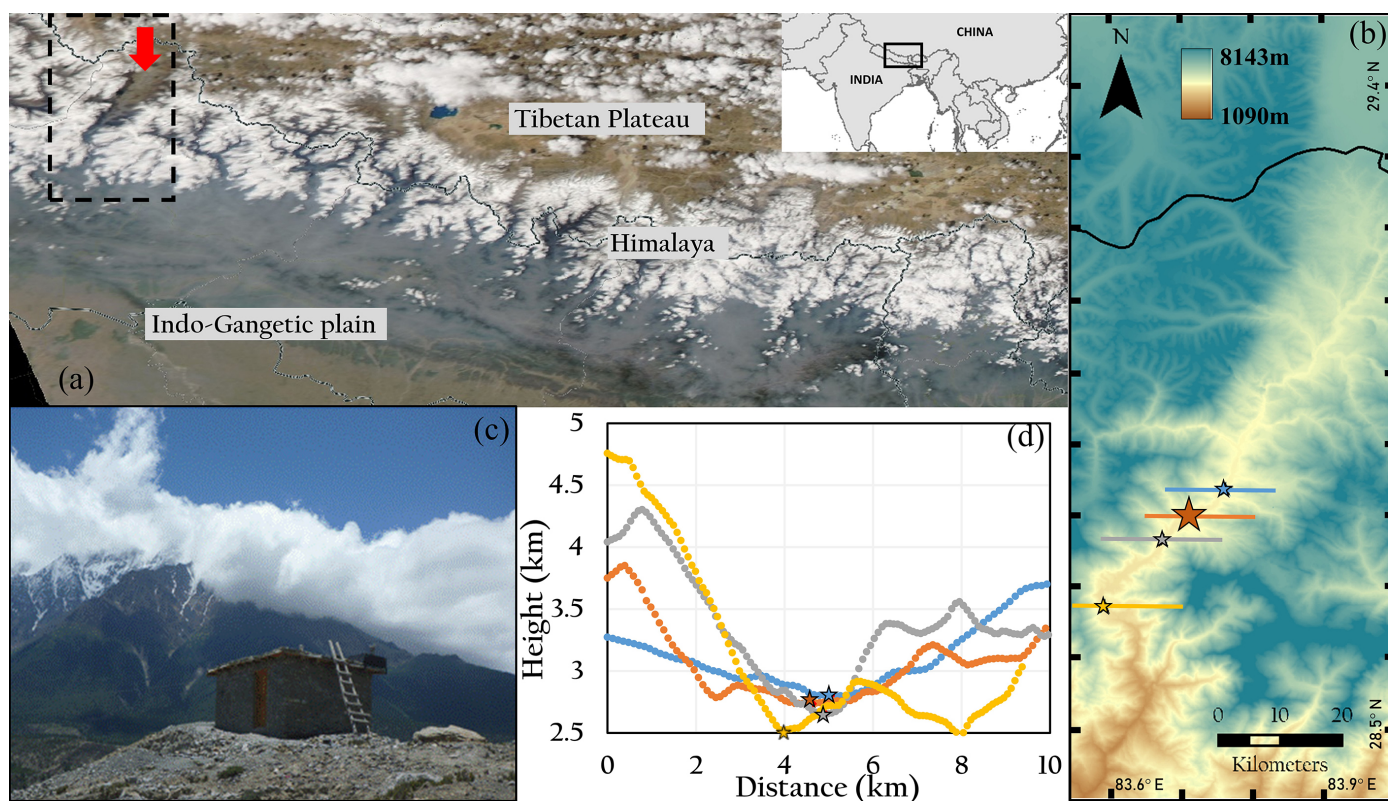

Figure 1. (a) NASA Worldview image from 4 November 2014 depicting thick haze intruding the Himalayan foothills with a red arrow over the KGV. Inset map in the top-right corner of (a) shows the location of the Worldview image. Dashed box shows the location of (b). (b) Expanded scale of the KGV showing station locations of Lete (LET_AWS) near the entrance of the valley (yellow star); Marpha (MPHAWS) in the core region (gray star); the Jomsom (JSM_STA) sampling station for BC and $\mathrm{O}_{3}$ and the two associated AWS sites (JSM_1 and JSM_2) in the core region (orange star); and Eklobhatti (EKL_AWS) near the exit (blue star). (c) The atmospheric observatory at Jomsom (JSM_STA) $\left(28.87^{\circ} \mathrm{N}, 83.73^{\circ} \mathrm{E}, 2900 \mathrm{~m}\right.$ a.s.1.). (d) Valley cross-sectional elevation profile at the station locations.

\section{Measurement sites and methods}

\subsection{Measurement sites and instrumentation}

This paper presents data from an atmospheric measurement station in Jomsom $\left(28.87^{\circ} \mathrm{N}, 83.73^{\circ} \mathrm{E}, 2900\right.$ ma.s.l. $)$ within the core region of the KGV along with four other automated weather stations (AWSs) up and down the valley from Jomsom (Fig. 1). With the exception of aerosol optical depth measured as part of AERONET (AErosol RObotic NETwork) (Xu et al., 2015) and a ${ }^{14} \mathrm{C}$ study at several sites in the Himalaya and TP, including Jomsom (Li et al., 2016), no pollution data from Jomsom have previously been reported. Here we report diurnal and seasonal trends in two important short-lived climate pollutants (SLCPs) - BC and $\mathrm{O}_{3}$ - to evaluate the role of trans-Himalayan valleys as pathways for the transport of polluted air from the IGP to the higher Himalaya.

The KGV is located in the Dhaulagiri zone of western Nepal (Fig. 1a). The KGV floor changes elevation from approximately 1100 to $4000 \mathrm{~m}$ a.s.l. over a horizontal distance of $90 \mathrm{~km}$ (Fig. 1b). Passing between the two $8000 \mathrm{~m}$ peaks of Dhaulagiri and Annapurna, it forms one of the deepest valleys in the world. The valley is a narrow gorge at the lower end and opens up into a wider arid basin (Fig. 1b) with a maximum width of approximately $1 \mathrm{~km}$. The orientation of the KGV varies from the entrance to the exit. The general orientation of the valley is from SW (the mouth of the val- ley) to NE (the head of the valley) (Fig. 1). Approximately 13000 inhabitants in several small settlements sparsely populate the valley. Emission sources within the valley include biofuel combustion for cooking and fossil-fuel combustion by off-road vehicles. There is an airport in Jomsom which operates only in the morning, as the narrow valley width and high up-valley wind speeds make it dangerous for small aircraft to land at other times during the day. A total of $5245 \mathrm{ve}$ hicles have been registered in Dhaulagiri zone since 2008, but most are based in the southern towns of Kusma, Baglung, and Beni, below $1 \mathrm{~km}$ altitude, at the lowest left corner of the map in Fig. 1b (DOTM, 2016).

The atmospheric observatory at Jomsom (JSM_STA) is equipped with instruments to measure $\mathrm{BC}, \mathrm{O}_{3}$, and meteorology (Table S1 in the Supplement). The observatory is located on the southeast corner of a plateau jutting out from an east-facing slope about $100 \mathrm{~m}$ above the valley floor and with no major obstructions either up or down the valley. Equivalent $\mathrm{BC}$ was measured with a Thermo Fisher 5012 Multiangle Absorption Photometer (MAAP) that uses a multi-angle photometer to analyze the modification of radiation fields - as caused by deposited particles that entered through a straight, vertical inlet line - in the forward and back hemisphere of a glass-fiber filter (GF-10). MAAP was operated at a flow rate of $20 \mathrm{~L} \mathrm{~min}^{-1}$ and measured BC at a 1 min frequency. We note that Hyvärinen (2013) illustrates the artifact in MAAP measurements in environments 
with high aerosol loading with an underestimation of concentrations above $9 \mu \mathrm{g} \mathrm{m}^{-3}$. Since the median monthly concentrations for the duration of the measurement were less than $1 \mu \mathrm{g} \mathrm{m}^{-3}$ and 90th-percentile measurements were below $2 \mu \mathrm{g} \mathrm{m}^{-3}$ (and therefore below this threshold), MAAP corrections were not applied. $\mathrm{O}_{3}$ was measured with a $2 \mathrm{~B}$ Technologies Model 205 via the attenuation of ultraviolet light at $254 \mathrm{~nm}$ passing through a $15 \mathrm{~cm}$ long absorption cell fitted with a quartz windows. The instrument was operated at a flow rate of $1.8 \mathrm{~L} \mathrm{~min}^{-1}$. For instrument calibration, the BC instrument performed an automatic span and zero checks every $24 \mathrm{~h}$, while zero checks on the $\mathrm{O}_{3}$ instrument were performed every 7 days. Wind speed and direction were measured by an automated weather station (JSM_2) installed on a ridge $800 \mathrm{~m}$ above the sampling site for $\mathrm{BC}$ and $\mathrm{O}_{3}$ (JSM_1).

\subsection{Data summary}

The observatory operated from January 2013 through July 2015, but periodic power disruptions caused occasional data gaps (Fig. 2). Unless otherwise noted, data reported herein correspond to periods when $\mathrm{BC}, \mathrm{O}_{3}$, and meteorological data were available simultaneously. Data were binned by season as follows: monsoon (July-September), postmonsoon (October-February), and pre-monsoon (MarchJune). Time of day corresponds to Nepal's local time zone (LT) (UTC + 5.75 h). From March 2015 to May 2015, four additional automated weather stations (10 $\mathrm{m}$ in height) were operated along a longitudinal transect of the valley floor where wind speeds are typically the highest: near the entrance of the valley at Lete (LET), within the core at Marpha (MPH) and Jomsom (JSM_2), and near the valley exit at Eklobhatti (EKL) (Fig. 1b). Power outages, instrument malfunctions, and a major earthquake in Nepal on 25 April 2015 (and its aftershocks) limited the duration of records at all sites. However, between 1 and 14 May, all stations operated simultaneously, and the resulting data were used to evaluate the diurnal variability of wind fields along the valley.

$\mathrm{BC}, \mathrm{O}_{3}$, and meteorological data were averaged over $10 \mathrm{~min}$ intervals. Up-valley (southwesterly) flows are defined as between 215 and $235^{\circ}$, while down-valley (northeasterly) flows include data between $35^{\circ}$ and $55^{\circ}$. Data for all days for which complete data were available over entire $24 \mathrm{~h}$ periods were binned by season. The statistical significance of differences between up-valley and down-valley flow conditions during different seasons were evaluated using the nonparametric Kruskal-Wallis and Mann-Whitney tests.

To normalize for the influence of day-to-day variability in absolute concentrations, relative diurnal variability in $\mathrm{O}_{3}$ and $\mathrm{BC}$ concentrations measured during a given month were normalized to a common scale ranging from 0 to 1 (see, e.g., Sander et al., 2003; Fischer et al., 2006). Normalized BC values for month $m$ were calculated as

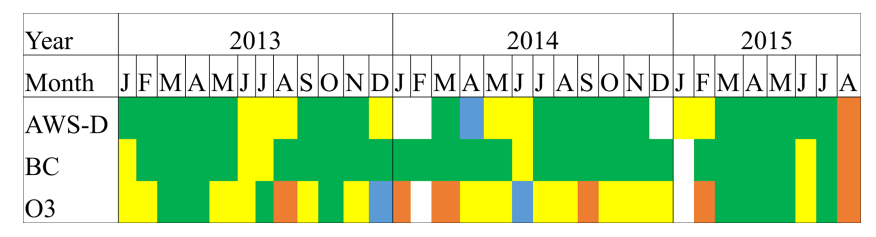

Figure 2. Data timeline for JSM_2 AWS, BC, and $\mathrm{O}_{3}$ measurements in Jomsom. Green indicates complete data, blue indicates only a few missing data points, yellow indicates more than 15 days of data, orange indicates less than 15 days of data, and white indicates no data.

$\mathrm{BC}_{n, t}=\frac{\mathrm{BC}_{t}-\operatorname{minBC}_{m}}{\operatorname{maxBC}_{m}-\operatorname{minBC}_{m}}$,

where $\mathrm{BC}_{t}$ is the $\mathrm{BC}$ concentration at time $t$ in the month $m$, and $\operatorname{maxBC}_{m}$ and $\operatorname{minBC}_{m}$ are the maximum and minimum $\mathrm{BC}$ concentrations observed during month $m$. The normalized data were then binned into 24 hourly increments. These calculations were repeated for $\mathrm{O}_{3}$.

\subsection{Preliminary flux estimates}

Up-valley and down-valley BC fluxes were calculated separately and determined using wind direction measurements. Instantaneous flux at time $t$ was calculated as

$j_{t}=\mathrm{BC}_{t} \mathrm{ws}_{t}$,

where $\mathrm{BC}_{t}$ is the $\mathrm{BC}$ concentration $\left(\mathrm{mgBCm}^{-3}\right)$ at time $t$ and $\mathrm{ws}_{t}$ is the wind speed $\left(\mathrm{m} \mathrm{s}^{-1}\right)$ at time $t$. From this, net daily mass transport $\left(M_{\mathrm{d}}\right)$ for day $d$ was estimated as

$M_{\mathrm{d}}=A\left(\sum\left(j_{t, \text { up }} \Delta t\right)-\sum\left(j_{t, \text { down }} \Delta t\right)\right)$,

where $A$ is the cross-sectional area of the valley at Jomsom $\left(1.41 \times 10^{6} \mathrm{~m}^{2}\right) ; j_{t, \text { up }}$ and $j_{t \text {, down }}$ are the instantaneous upvalley and down-valley fluxes, respectively, occurring during day $d$; and $\Delta t$ is the length of each time step in seconds (i.e., $600 \mathrm{~s}$ ). The cross-sectional area was estimated as a trapezoid with a height of $800 \mathrm{~m}$ (the difference in elevation between the two Jomsom stations) and cross-valley distances of $800 \mathrm{~m}$ (at JSM_1) and $2720 \mathrm{~m}$ (at JSM_2). The average of these two cross-valley distances $(1760 \mathrm{~m})$ multiplied by the height $(800 \mathrm{~m})$ yields the cross-sectional area of $1.41 \times 10^{6} \mathrm{~m}^{2}$. Thus, net daily flux was calculated as the difference between the summation of instantaneous up-valley fluxes for day $d$ and the summation of instantaneous downvalley fluxes for day $d$.

If we assume that (1) the polluted boundary layer within the valley at Jomsom is $800 \mathrm{~m}$ deep (i.e., the approximate elevational difference between the two AWS sites at Jomsom), (2) BC within the polluted boundary layer is well mixed, and (3) wind velocities do not vary significantly with altitude 

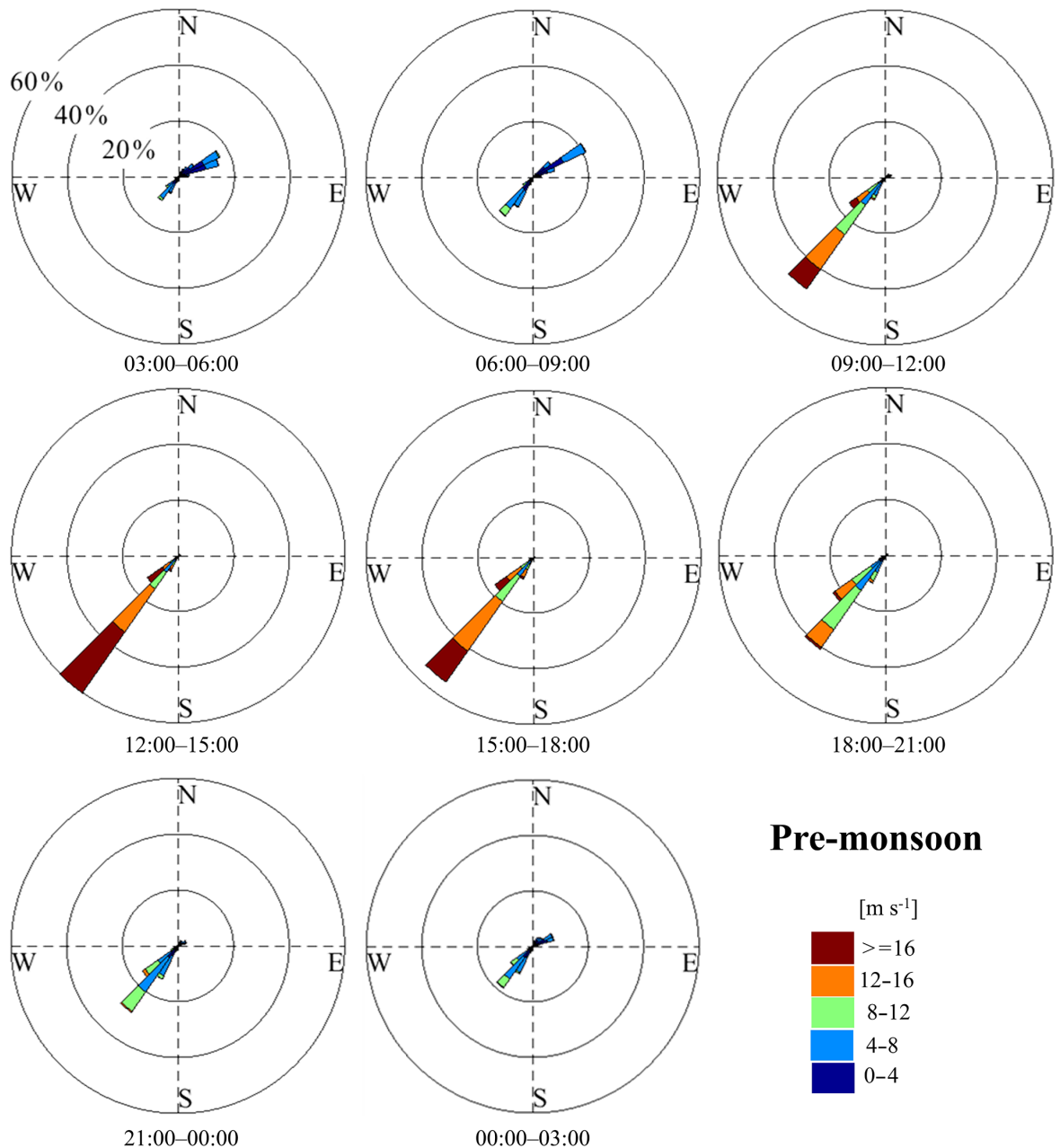

\section{Pre-monsoon}

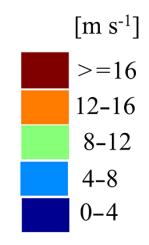

Figure 3. Wind rose for pre-monsoon season - binned into $3 \mathrm{~h}$ increments depiciting diurnal evolution in wind speed and direction at JSM_2.

through the polluted layer, the mass flux of BC through a vertical plane across the valley can be estimated. Figure S1 in the Supplement shows that JSM_2 is well within the polluted haze layer during daytime/up-valley flows and that some BC is almost certainly transported above $800 \mathrm{~m}$ elevation above the valley floor. In addition, it is important to note that - by assuming a constant polluted boundary layer depth throughout the day - to a certain degree we likely underestimate up-valley flux during daytime and overestimate down-valley flux during nighttime. We therefore ensure that our estimates are conservative. The long atmospheric lifetime of particulate BC (several days to a week or more) - coupled with turbulent flow within the valley - supports the assumption that $\mathrm{BC}$ is well mixed. Figure $\mathrm{S} 2$ shows that the potential temperature (theta) gradient is less than zero between JSM_1 and JSM_2, which illustrates that the air within the valley is unstable. In addition, Egger et al. (2000) used theodolite measurements to demonstrate uniform wind speeds within the bottom $1000 \mathrm{~m}$ above the KGV floor at Jomsom and other locations. While we observed differences in wind speed of $\sim 5 \mathrm{~m} \mathrm{~s}^{-1}$ between the two Jomsom stations during the limited times when data were available from both, we were unable to determine whether this pattern persisted throughout the year. These data limitations also prevented us from a more in-depth assessment of potential nighttime decoupling. For these reasons, our only option was to follow the findings of Egger et al. (2000) and assign the wind speed at JSM_2 to the entire flux plane.

\section{Results and discussion}

\subsection{Evolution of local wind systems in the KGV}

An understanding of the local wind regime is essential for analyzing pollution transport through mountain valleys. Measurements from JSM_2 show the diurnal evolution of wind at Jomsom in each season (Figs. 3 and S4). At JSM_2, upvalley flows are southwesterly and dominant during daytime, with peak velocities above $15 \mathrm{~m} \mathrm{~s}^{-1}$ between 09:00 

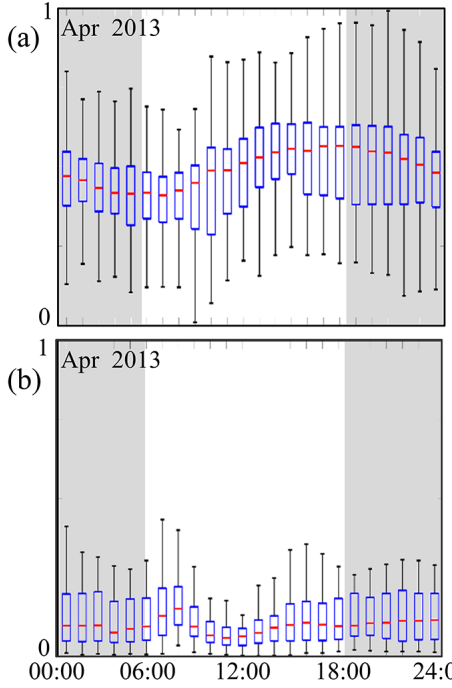
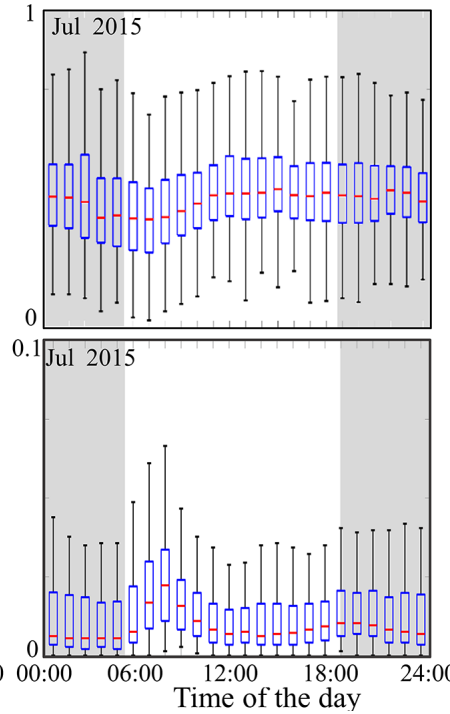

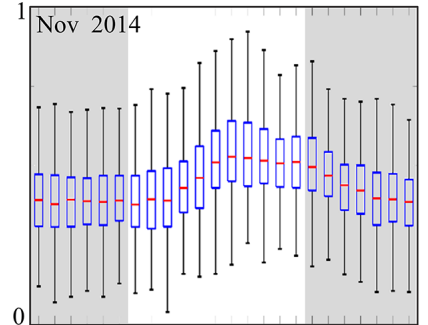

$1 \longdiv { \text { Nov } 2 0 1 4 }$

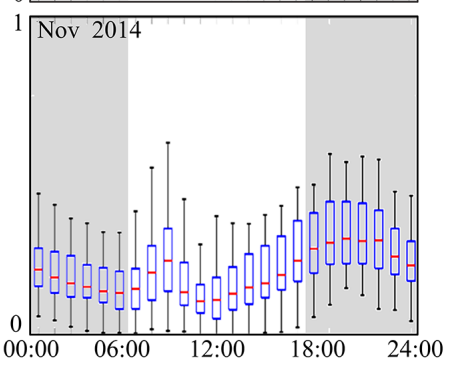

Figure 4. Box-and-whisker plots depicting the 90th, 75th, 50th, 25th, and 10th percentiles for normalized diel variability in $\mathrm{O}_{3}$ (a) and $\mathrm{BC}^{(\mathbf{b})}$ at JSM_STA during April 2013 (pre-monsoon), August 2014 (monsoon), and November 2014 (post-monsoon). Scale for August 2014 is from 0 to 0.1 .

and 18:00 LT. Wind velocities decreased substantially after 18:00 LT, with variable wind direction until midnight, followed by northeasterly winds (during pre- and post-monsoon seasons (Figs. 3 and S4b). The wind patterns during monsoon appear strongly influenced by the monsoon anticyclone, an observation which is in agreement with wind direction measurements from other Himalayan valleys (Bonasoni et al., 2010; Ueno et al., 2008) (Fig. S4a). Although wind velocities at JSM_2 varied over the year, non-monsoon months exhibited similar diurnal patterns as a function of sunrise and sunset (Figs. 3 and S4). As discussed below, this alternating pattern in wind direction from strong daytime flows to weak nighttime flows during dry months resulted in a net transport of pollutants up the valley.

Our measurements at the four AWS stations on the valley floor illustrated the evolution of surface wind velocities along the length of the KGV (Fig. S3). In general, wind speeds along the valley floor were strongest within the core of the valley at MPH, JSM_1, and JSM_2 and were weaker in the entrance (LET) and exit (EKL) regions (Fig. S3). The observation of these strong daytime wind speeds within the valley during the monsoon is consistent with the hypothesis that wind patterns are modulated by a pressure gradient created from the differential heating of the arid valley floor relative to the mouth of the valley (Egger et al., 2000). In addition, our comparison of measurements at JSM_1 and JSM_2 (Figs. 3, $\mathrm{S} 3$, and $\mathrm{S} 4 \mathrm{a}$ and $\mathrm{b}$ ) provided information regarding vertical variability in wind speed. Velocities at the higher-elevation site of JSM_2 were about 5 and $3 \mathrm{~m} \mathrm{~s}^{-1}$ greater than those near the valley floor during daytime and nighttime, respectively. The two sites exhibited similar diurnal cycles with the exception of a relatively stronger northeasterly wind at JSM_2 from 03:00 to 09:00 LST.

\subsection{Diurnal variability in $\mathrm{BC}$ and $\mathrm{O}_{3}$}

Based on median values, $\mathrm{O}_{3}$ peaked during daytime and dropped to minimal levels before sunrise during all three study seasons (pre-monsoon, monsoon, and post-monsoon). However, in April 2013 (pre-monsoon period), $\mathrm{O}_{3}$ peaked in the late afternoon, whereas in November 2014 (postmonsoon) it peaked in the early afternoon. In addition, the normalized diurnal excursions were greater during the preand post-monsoon periods than during the monsoon period represented by August 2014. In contrast, BC concentrations increased rapidly in the early morning, decreased during late morning, and then rose again during the afternoon and early evening hours (Fig. 4); this pattern was consistent across all seasons, with relative diurnal variability being somewhat greater during post-monsoon than during the pre-monsoon and monsoon periods. Across all seasons, the lower normalized distributions for $\mathrm{BC}$ than $\mathrm{O}_{3}$ reflect infrequent periods of high $\mathrm{BC}$ concentrations.

Several factors likely contributed to differences in timing of the daily peaks in $\mathrm{O}_{3}$ and $\mathrm{BC}$ concentrations. These include potentially different source regions for $\mathrm{BC}$ and $\mathrm{O}_{3}$ precursors, the timing of the photochemical production and destruction of $\mathrm{O}_{3}$, and contributions of $\mathrm{O}_{3}$ and its precursors from non-combustion sources like stratospheric ozone and biogenic hydrocarbons from vegetation. The early-morning $\mathrm{BC}$ peak during all seasons suggests contributions from the local combustion of biofuels for cooking and heating, which are most prevalent during early morning. The secondary peak 
in the afternoon and early evening occurred when the local anthropogenic emission sources were at a minimum in the KGV.

\subsection{Seasonal variability in $\mathrm{BC}$ and $\mathrm{O}_{3}$}

All data generated during the measurement period were binned by month to evaluate the seasonal patterns of $\mathrm{BC}$ and $\mathrm{O}_{3}$ (Fig. 5). In addition, individual months with the most complete data coverage during the pre-monsoon (April 2013), monsoon (August 2014), and post-monsoon (November 2014) seasons were selected to evaluate aspects of temporal variability in greater detail (Fig. 6). We divided the seasons into dry (pre-monsoon, post-monsoon) and wet (monsoon) seasons to understand the transport of pollutants via Himalayan valleys in the presence and absence of wetdeposition processes. Based on median values, the highest concentrations of both species occurred during the months preceding the monsoon, and the lowest were during months of the monsoon. The significantly lower concentrations of both species during the monsoon reflected the combined influences of synoptic easterly airflow that transports a cleaner marine air mass over the region, reduced agricultural residue burning (Sarangi et al., 2014), and more efficient aerosol removal via wet deposition (Dumka et al., 2010). In addition to the possible active wet deposition of $\mathrm{O}_{3}$ precursors during the monsoon season, increased cloudiness during monsoon may also reduce $\mathrm{O}_{3}$ production (Lawrence and Lelieveld, 2010).

The post-monsoon timing of peak $\mathrm{BC}$ concentrations observed in previous studies performed in the IGP and Himalayan foothills (see, e.g., Tripathi et al., 2005, 2007; Ramchandran and Rajesh, 2007; Putero et al., 2015) differs from our observations in the KGV, where we see heightened BC during the pre-monsoon season (Fig. 5). These findings are generally in agreement with other high-altitude observations. For example, the Nepal Climate Observatory - Pyramid (NCO-P) station at 5079 ma.s.l. in the Himalaya has also shown high seasonal differences for $\mathrm{BC}$ and $\mathrm{O}_{3}$ between pre-monsoon $\left(0.444( \pm 0.443) \mu \mathrm{g} \mathrm{m}^{-3} \mathrm{BC}\right.$; $\left.61( \pm 9) \mathrm{ppbv} \mathrm{O}_{3}\right)$ and monsoon $\left(0.064( \pm 0.101) \mathrm{\mu g} \mathrm{m}^{-3} \mathrm{BC}\right.$; $\left.39( \pm 10) \mathrm{ppbv} \mathrm{O}_{3}\right)$ (Cristofanelli et al., 2010; Marinoni et al., 2013) (Table 1). Our results therefore indicate a lagged peak in $\mathrm{BC}$ and $\mathrm{O}_{3}$ within the $\mathrm{KGV}$ and presumably other deep Himalayan valleys, as compared to sites within the IGP.

\subsection{Local winds as drivers of $\mathrm{BC}$ and $\mathrm{O}_{3}$ transport in the KGV}

Figure 6 shows the time series of $\mathrm{BC}$ and $\mathrm{O}_{3}$ during an individual month in each season (April, pre-monsoon; August, monsoon; November, post-monsoon). For April, BC concentrations peaked at 07:00 LST (Fig. 6), when wind velocities were low (Fig. 6). This peak occurred about an hour later in November, with both periods experiencing a decrease in $\mathrm{BC}$ over the rest of the morning as wind speeds increased

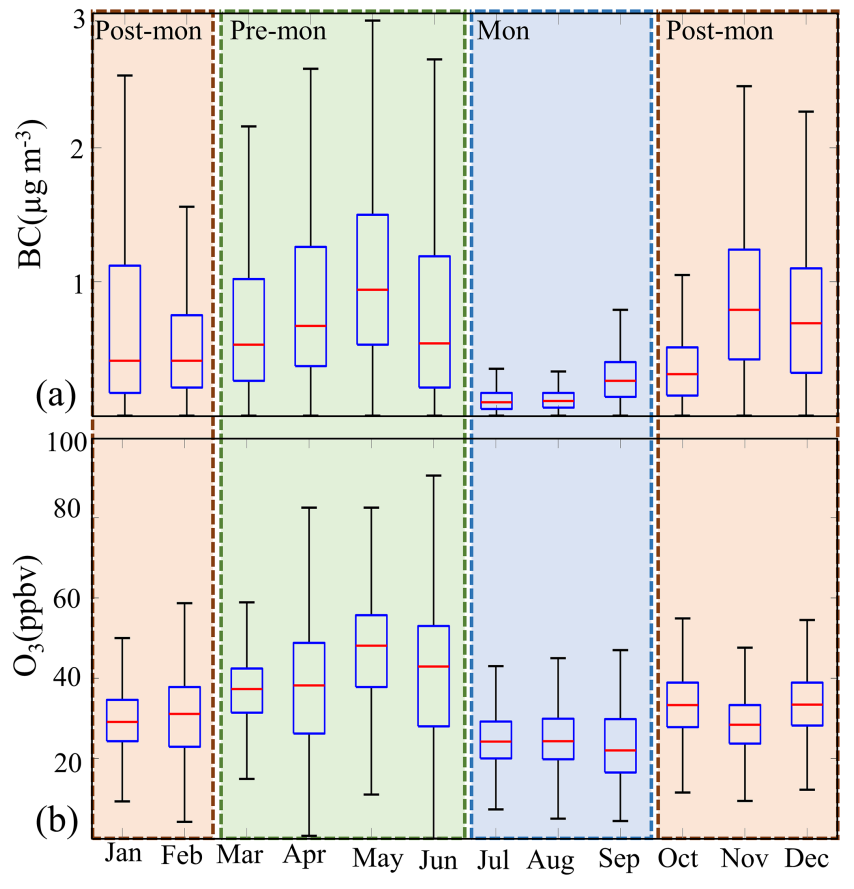

Figure 5. Box-and-whisker plots depicting the 90th, 75th, 50th, 25th, and 10th percentiles for monthly concentrations of BC (a) and $\mathrm{O}_{3}$ (b) between January 2013 and August 2015 at JSM_STA. Orange shaded areas indicate the post-monsoon season (Post-mon), green shaded area indicates the pre-monsoon (Pre-mon), and blue are indicates the monsoon (Mon) season.

and diluted local emissions (Fig. 4). Thereafter, BC concentrations increased over the afternoon and early night, reaching secondary peaks near midnight LST in April and several hours earlier in November and August (Figs. 4 and 6). Distinct morning and afternoon peaks in BC concentration were seen in the post-monsoon season, when the up-valley wind speeds were relatively weaker than in the pre-monsoon season (Figs. 4 and 6). The bimodal diurnal distribution of $\mathrm{BC}$ concentration in Jomsom was similar to that observed in Kathmandu (Putero et al., 2015) but unlike a singular lateafternoon/evening peak seen at high-elevation sites (Bonasoni et al., 2010) during non-monsoonal seasons. This illustrates that deep Himalayan valleys are susceptible to diurnal pollution similar to that of urban areas like Kathmandu. The morning peak in $\mathrm{BC}$ was most likely due to local pollutants (from household and morning aircraft traffic) in Jomsom and settlements downwind of Jomsom, while the afternoon peak was likely primarily associated with long-range transport in addition to local pollutants. However, the contribution of long-range transport relative to local sources of pollutants is not known. At the same time, $\mathrm{O}_{3}$ exhibited a distinct minimum in the early morning, with concentrations increasing towards an early afternoon peak - occurring well before BC's afternoon peak. The $\mathrm{O}_{3}$ minimum in the morning provided further evidence that the morning $\mathrm{BC}$ peak origi- 

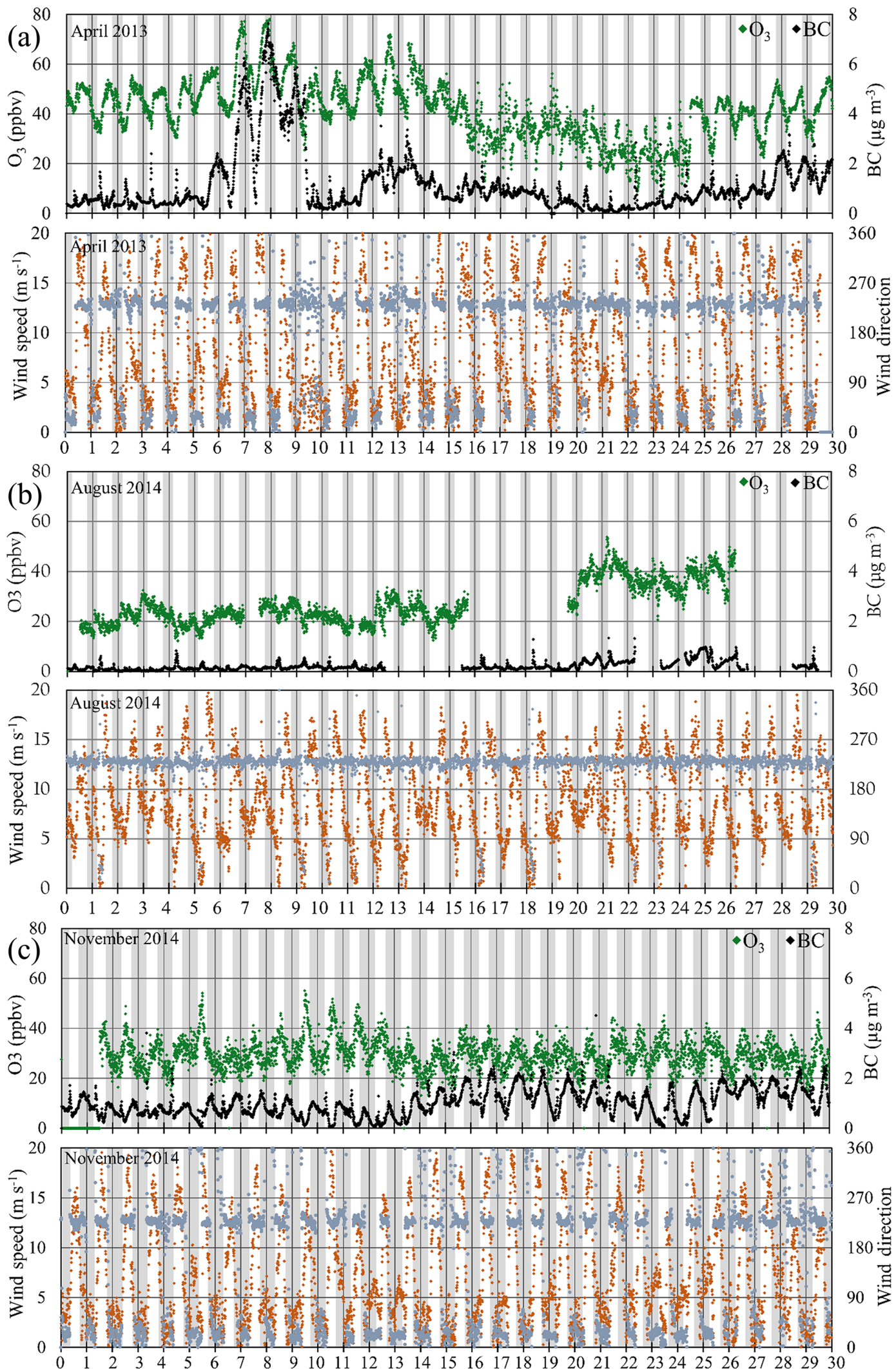

Figure 6. Variation in $\mathrm{O}_{3}$, BC, and associated wind speed and direction at JSM_STA during (a) April 2013 (pre-monsoon), (b) July 2015 (monsoon), and (c) November 2014 (post monsoon). The gray shaded area denotes night. 
Table 1. Comparison of $\mathrm{BC}$ and $\mathrm{O}_{3}$ concentrations (mean $\pm \mathrm{SD}$ ) between high-elevation Himalayan site NCO-P and JSM_1.

\begin{tabular}{lcclll}
\hline Sites & Altitude $(\mathrm{m})$ & Co-ordinates & Season & $\mathrm{BC}\left(\mu \mathrm{g} \mathrm{m}^{-3}\right)$ & $\mathrm{O}_{3}(\mathrm{ppb})$ \\
\hline NCO-P & 5079 & $27.95^{\circ} \mathrm{N}, 86.81^{\circ} \mathrm{E}$ & Pre-monsoon & $0.32( \pm 0.34)$ & $60.9( \pm 8.4)$ \\
(Bonasoni et al., 2010) & & & Monsoon & $0.05( \pm 0.06)$ & $38.9( \pm 9.0)$ \\
& & & Post-monsoon & $0.14( \pm 0.08)$ & $46.3( \pm 5.0)$ \\
JSM_1 & \multirow{2}{*}{2800} & $28.87^{\circ} \mathrm{N}, 83.73^{\circ} \mathrm{E}$ & Pre-monsoon & $0.90( \pm 0.45)$ & $39.5( \pm 8.23)$ \\
& & & Monsoon & $0.21( \pm 0.24)$ & $25.1( \pm 6.48)$ \\
& & & Post-monsoon & $0.71( \pm 0.42)$ & $31.4( \pm 4.50)$ \\
\hline
\end{tabular}

(a)

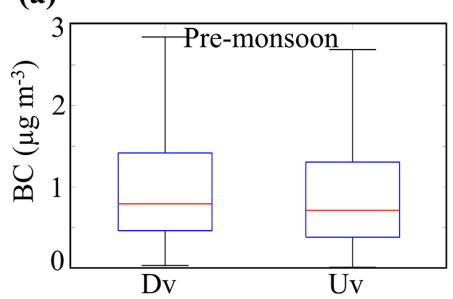

(b)

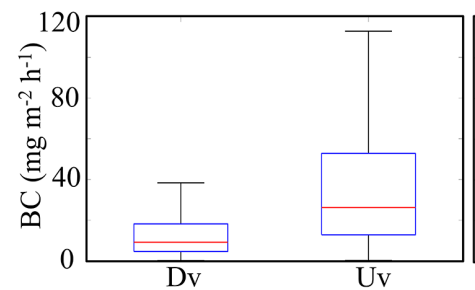

(c)

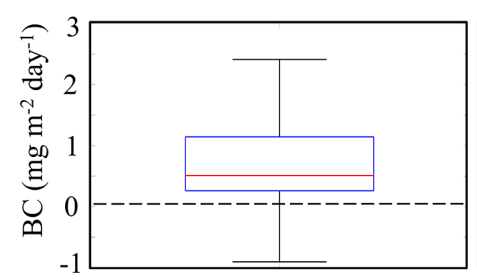

$\mathrm{BC}$ concentration

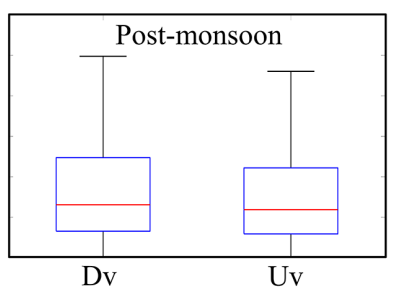

$\mathrm{BC}$ flux
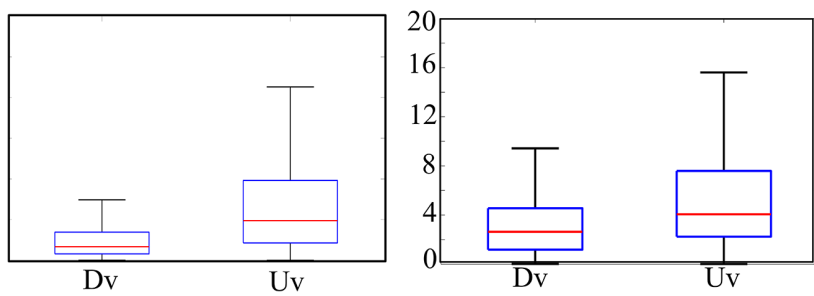

Net daily BC flux
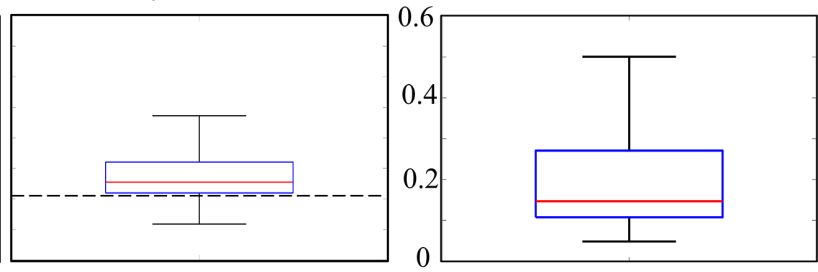

Figure 7. (a) BC concentration distribution with down-valley (Dv) and up-valley (Uv) flows in Jomsom, (b) calculated Dv and Uv flux for each season, (c) net daily flux per season. The dotted line in (c) marks $0 \mathrm{mg} \mathrm{m}^{-2}$ day $^{-1}$ (pre- and post-monsoon are from -1 to $3 \mathrm{mg} \mathrm{m}^{-2} \mathrm{day}^{-1}$ and from 0 to $0.6 \mathrm{mg} \mathrm{m}^{-2} \mathrm{day}^{-1}$, respectively). The red line represents 50th percentile, the edge of the box represents the 25 th and 75 th percentile, and the whiskers show maximum and minimum values. Scale for monsoon season is $0-1 \mu \mathrm{g} \mathrm{m}{ }^{-3}$ for $\mathrm{BC}$ concentrations, $0-20 \mathrm{mg} \mathrm{m}^{-2} \mathrm{~h}^{-1}$ for BC flux, and $0-0.6 \mathrm{mg} \mathrm{m}^{-2}$ day $^{-1}$ for net daily BC flux.

nated from local sources, as $\mathrm{O}_{3}$ is only formed downwind of pollution sources. Further, the Jomsom station measuring BC and $\mathrm{O}_{3}$ (JSM_STA) was located more than $100 \mathrm{~m}$ above the valley floor - where the village of Jomsom sits. As such, we do not expect that local evening emissions would have reached the station at the cessation of up-valley flows and that evening drainage flows, following the valley floor, would remove these local evening emissions down-valley.

Percentage distributions of up-valley and down-valley BC concentrations, up-valley and down-valley fluxes, and net daily fluxes are depicted in Fig. 7 and summarized in Table S2. Up-valley and down-valley BC concentrations were quite similar - with down-valley concentrations being slightly higher - but were found to be statistically significantly different for all seasons (Fig. 7a). However, because wind velocities were relatively stronger during upvalley daytime flows and the duration of up-valley flows was longer than that of down-valley flow, the corresponding upvalley fluxes of $\mathrm{BC}$ during daytime were markedly and significantly greater than down-valley fluxes, across all seasons (Fig. 7b). These results suggest an oscillatory movement of polluted air within the valley, where polluted air masses are pushed up-valley during daytime and retreat a shorter distance during nighttime. These differences between up-valley 
and down-valley fluxes yielded significant net daily up-valley fluxes of $\mathrm{BC}$ during all seasons (Fig. 7c). Because heating would have driven growth of the boundary layer - thereby enhancing the ventilation and dilution of pollutants during daytime relative to night - we infer that the calculated differences between up-valley and down-valley fluxes correspond to the lower limits for net BC fluxes.

Positive up-valley fluxes were consistent with an alpine pumping mechanism in the Himalayan valleys and therefore support the hypothesis that these valleys are important pathways for pollution transport. In addition, we estimated substantial net daily mass transport of $\mathrm{BC}$ up the valley during the pre-monsoon season: $1.05 \mathrm{~kg} \mathrm{day}^{-1}$ (based on the average net daily flux) and $0.72 \mathrm{~kg} \mathrm{day}^{-1}$ (based on the median net daily flux). While preliminary, these estimates provide the first semi-quantitative constraints on the mass transport of BC from the IGP to the high Himalaya through deep valleys. More generally, these fluxes have important implications for the regional cycling of $\mathrm{BC}$ throughout southern Asia.

\subsection{Evidence of regional-transport episodes in valley concentration}

Along with the regular diurnal and seasonal variability driven by local winds as described above, we also observed anomalous periods - lasting several days to more than a week during which $\mathrm{BC}$ concentrations were significantly greater than the 90th percentile for corresponding annual averages (Table 2). These extended periods of high BC were evidence of large-scale transport from the IGP to the Himalayan foothills in conjunction with local valley winds (Fig. 8). Elevated $\mathrm{O}_{3}$ concentrations did not always accompany these long-duration periods of high $\mathrm{BC}$ concentrations above the 90 th percentile. Different atmospheric lifetimes, chemical reactivity, source location, and sinks of $\mathrm{BC}$ and $\mathrm{O}_{3}$ may have contributed to these differences in $\mathrm{BC}$ and $\mathrm{O}_{3}$ concentrations detected in the valley. Table 2 reports the number of days in which $\mathrm{O}_{3}$ concentration was above the 90th percentile within each episode.

We partitioned these episodes into three characteristic patterns based on the relative variability of BC. Pattern A was characterized as a fluctuating daily maximum in $\mathrm{BC}$ with peaks that repeatedly exceeded the 90th percentile but with daily minima below the 90th percentile (Fig. 8Ia). Pattern B was characterized by a steady buildup of BC concentration over the period of the regional-transport episode, with peak BC concentrations over the 90th percentile but without a daily minimum (Fig. 8b). Pattern C exhibited a combination of both patterns $\mathrm{A}$ and $\mathrm{B}$ during a single regional episode (Fig. 8c). A total of 34 regional episodes were identified from January 2013 through June 2015, of which $47 \%$ were categorized as pattern A, $32 \%$ as pattern B, and $21 \%$ as pattern $\mathrm{C}$. The wind speeds at Jomsom during these transport episodes exhibited diurnal variability similar to those during other periods (Fig. 8II). During the regional-transport
Table 2. List of enhanced BC episodes observed at JSM_STA and the concurring regional sources from MODIS.

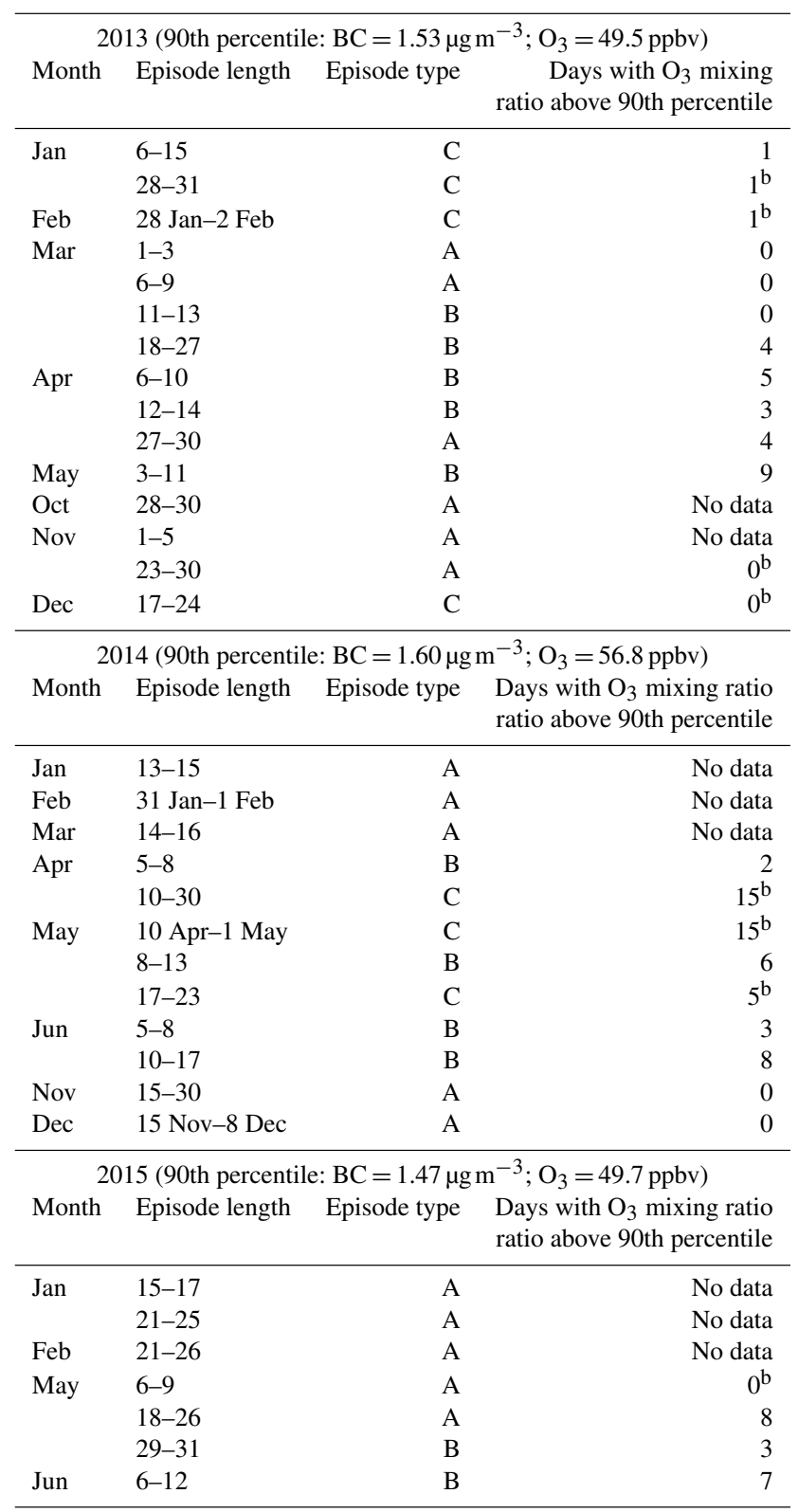

${ }^{\text {a }}$ Data is from January-July. ${ }^{\text {b }}$ Incomplete $\mathrm{O}_{3}$ data.

period in November 2014 (pattern A), average daily BC concentration was $1.3 \mu \mathrm{g} \mathrm{m}^{-3}$, which is over the 75 th percentile $\left(0.9 \mu \mathrm{g} \mathrm{m}^{-3}\right)$ of the BC concentration for the measurement duration. The maximum daily concentration during the period was $3.1 \mathrm{\mu g} \mathrm{m}^{-3}$. However, the corresponding average $\mathrm{O}_{3}$ was only $28.1 \mathrm{ppbv}$, slightly below the average (29.5 ppbv) for the entire data set (Fig. 8Ia). The mean BC concentration during a May 2014 pattern B transport episode was $1.8 \mu \mathrm{g} \mathrm{m}^{-3}$ (Fig. 8Ib). It was above the 90th percentile $\left(1.5 \mu \mathrm{g} \mathrm{m}^{-3}\right)$ for the entire measurement period, while $\mathrm{O}_{3}$ concentrations were at $49.7 \mathrm{ppbv}$, slightly below the 90th 

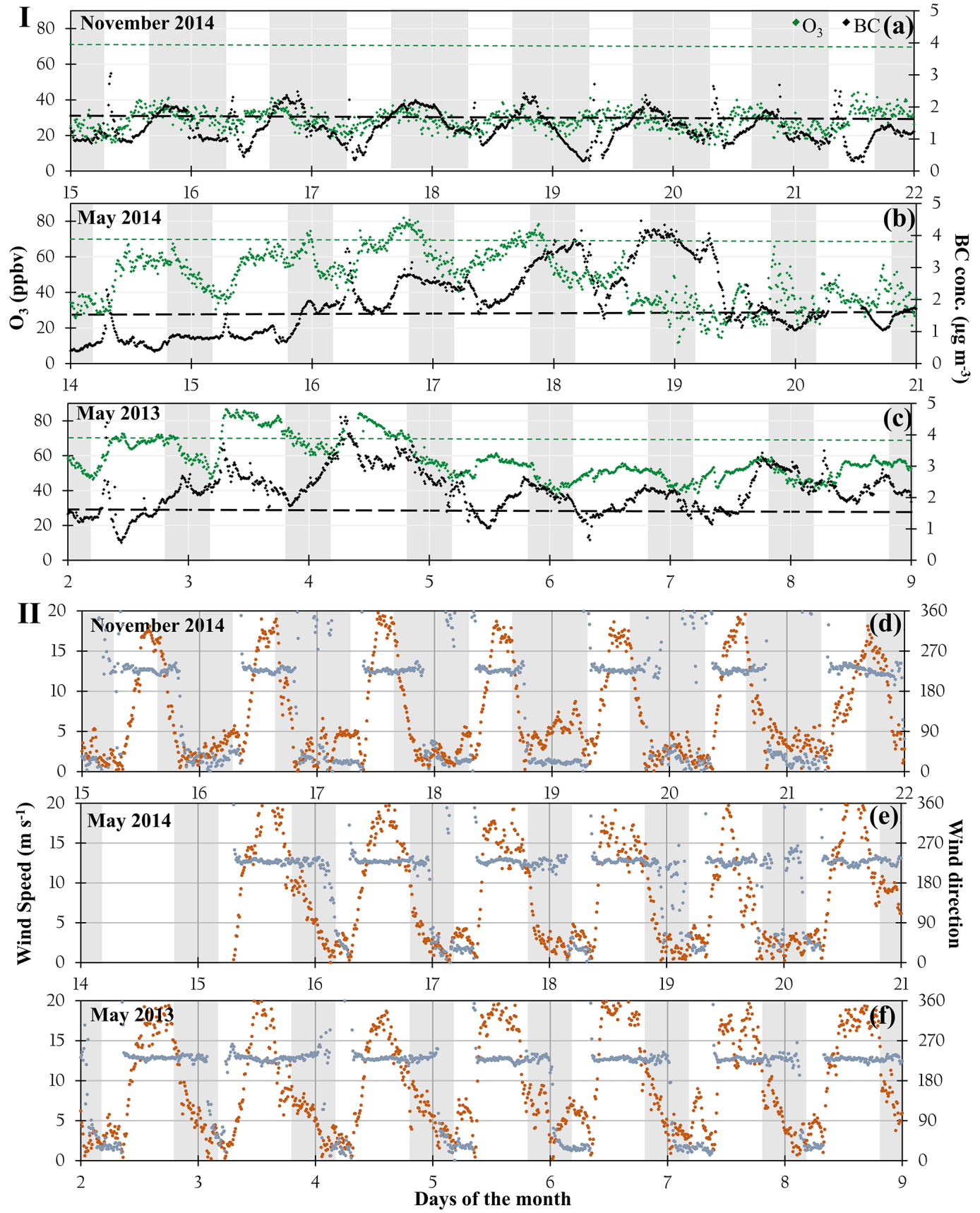

Figure 8. (I) Examples of extended periods with relatively high BC and $\mathrm{O}_{3}$ concentrations at JSM_STA during November 2014 (a), May 2014 (b), and May 2013 (c). The dashed black and green lines depict 2-year averages for $\mathrm{BC}$ and $\mathrm{O}_{3}$, respectively. (II) Corresponding wind direction and wind speed during the episodes of high $\mathrm{BC}$ and $\mathrm{O}_{3}$. The orange dots represent wind speed, and the blue dots represent wind direction.

percentile (52.9 ppbv). One of the pattern $\mathrm{C}$ type transport episodes was identified in May 2013, when the average concentration was well above the 90th percentile for both BC $\left(2.1 \mathrm{\mu g} \mathrm{m}^{-3}\right)$ and $\mathrm{O}_{3}(57.5 \mathrm{ppbv})$ (Fig. 8Ic). The diurnal wind pattern in the KGV was conserved during the pattern A example, but a longer period of up-valley flows occurred during the examples for patterns B and C (Fig. 8).

\section{Conclusion}

This study provides new in situ observational evidence of the role of a major Himalayan valley as an important pathway for transporting air pollutants from the IGP to the higher Himalaya. We found that concentrations of $\mathrm{BC}$ and $\mathrm{O}_{3}$ in the KGV exhibited systematic diurnal and seasonal variabil- 
ity. The diurnal pattern of $\mathrm{BC}$ concentrations during the preand post-monsoon seasons were modulated by the pulsed nature of up-valley and down-valley flows. Seasonally, premonsoon $\mathrm{BC}$ concentrations were higher than in the postmonsoon season. We also found that morning and afternoon peaks in the post-monsoon season were more pronounced than those of pre-monsoon season, likely due to the relatively lower wind speeds post-monsoon. Significant positive up-valley fluxes of $\mathrm{BC}$ were measured during all seasons, and preliminary flux estimates (which require a more robust estimate in future work) show the efficiency and magnitude of pollutant transport up the valley. During episodes of regional pollution over the IGP, relatively higher concentrations of BC and $\mathrm{O}_{3}$ were also measured in the $\mathrm{KGV}$.

The frequency and magnitude of pollution events highlighted in the paper need to be studied for a longer period in order to understand the associated interannual variability. In addition, future work should focus on understanding the vertical and horizontal distribution of particulate matter and ozone in the Himalayan region, and their impacts on the radiative budget, the ASM, and regional climate.

Data availability. All data are available upon requests made to the corresponding author.

\section{The Supplement related to this article is available online at https://doi.org/10.5194/acp-18-1203-2018-supplement.}

Competing interests. The authors declare that they have no conflict of interest.

Special issue statement. This article is part of the special issue "Atmospheric pollution in the Himalayan foothills: The SusKat-ABC international air pollution measurement campaign". It is not affiliated with a conference.

Acknowledgements. We would like to acknowledge our field assistant in Nepal, Buddhi Lamichhane, who helped us in various stages of the study, as well as the logistic and administrative support and Internet connection at the Jomsom station provided by Nepal Wireless. Financial support was provided by the National Aeronautics and Space Administration (NNX12AC60G), and additional field support was provided by ICIMOD's Atmosphere Initiative. This study was partially supported by core funds of ICIMOD contributed by the governments of Afghanistan, Australia, Austria, Bangladesh, Bhutan, China, India, Myanmar, Nepal, Norway, Pakistan, Switzerland, and the UK. The authors are very thankful for comments from William Keene, Jennie Moody, and Kyle Davis.
Edited by: Elizabeth Stone

Reviewed by: four anonymous referees

\section{References}

Andreae, M. O. and Crutzen, P. J.: Atmospheric aerosols: biogeochemical sources and role in atmospheric chemistry, Science, 1052-1058, 1997.

Auffhammer, M., Ramanathan, V., and Vincent, J. R.: Integrated model shows that atmospheric brown clouds and greenhouse gases have reduced rice harvests in India, P. Natl. Acad. Sci. USA, 103, 19668-19672, https://doi.org/10.1073/pnas.0609584104, 2006.

Bonasoni, P., Laj, P., Marinoni, A., Sprenger, M., Angelini, F., Arduini, J., Bonafè, U., Calzolari, F., Colombo, T., Decesari, S., Di Biagio, C., di Sarra, A. G., Evangelisti, F., Duchi, R., Facchini, MC., Fuzzi, S., Gobbi, G. P., Maione, M., Panday, A., Roccato, F., Sellegri, K., Venzac, H., Verza, G. P., Villani, P., Vuillermoz, E., and Cristofanelli, P.: Atmospheric Brown Clouds in the Himalayas: first two years of continuous observations at the Nepal Climate Observatory-Pyramid (5079 m), Atmos. Chem. Phys., 10, 7515-7531, https://doi.org/10.5194/acp-107515-2010, 2010.

Bond, T., Doherty, S., Fahey, D., Forster, P., Berntsen, T., DeAngelo, B., Flanner, M., Ghan, S., Kärcher, B., and Koch, D.: Bounding the role of black carbon in the climate system: a scientific assessment, J. Geophys. Res.-Atmos., 118, 5380-5552, https://doi.org/10.1002/jgrd.50171, 2013.

Brun, J., Shrestha, P., and Barros, A. P.: Mapping aerosol intrusion in Himalayan valleys using the Moderate Resolution Imaging Spectroradiometer (MODIS) and Cloud Aerosol Lidar and Infrared Pathfinder Satellite Observation (CALIPSO), Atmos. Environ., 45, 6382-6392, 2011.

Chen, P., Li, C., Kang, S., Rupakheti, M., Panday, A. K., Yan, F., Li, Q., Zhang, Q., Guo, J., and Ji, Z.: Characteristics of Particulate-Phase Polycyclic Aromatic Hydrocarbons (PAHs) in the atmosphere over the central Himalayas, Aerosol Air Qual. Res., 12, 2942-2954, https://doi.org/10.4209/aaqr.2016.09.0385, 2017.

Cristofanelli, P., Bracci, A., Sprenger, M., Marinoni, A., Bonafè, U., Calzolari, F., Duchi, R., Laj, P., Pichon, J. M., Roccato, F., Venzac, H., Vuillermoz, E., and Bonasoni, P.: Tropospheric ozone variations at the Nepal Climate ObservatoryPyramid (Himalayas, $5079 \mathrm{~m}$ a.s.1.) and influence of deep stratospheric intrusion events, Atmos. Chem. Phys., 10, 6537-6549, https://doi.org/10.5194/acp-10-6537-2010, 2010.

Dey, S. and Di Girolamo, L.: A climatology of aerosol optical and microphysical properties over the Indian subcontinent from $9 \mathrm{yr}$ (2000-2008) of Multiangle Imaging Spectroradiometer (MISR) data, J. Geophys. Res., 115, D15204, https://doi.org/10.1029/2009JD013395, 2010.

DOTM: Vehicle data zonal wise till 2072 Baishakh, Government of Nepal, Department of Transportation Management, available at: http://www.dotm.gov.np/uploads/files/ Vehicle-data-zonal-wise-till-2072-baishakh.pdf, last access: 26 March 2016.

Dumka, U. C., Krishna Moorthy, K., Satheesh, S. K., Sagar, R., and Pant, P.: Short-period modulations in aerosol opti- 
cal depths over the central Himalayas: role of mesoscale processes, J. Appl. Meteorol. Clim., 47, 1467-1475, https://doi.org/10.1175/2007JAMC1638.1, 2008.

Dumka, U. C., Krishna Moorthy, K., Kumar, R., Hegde, P., Sagar, R., Pant, P., Singh, N., and Suresh Babu, S.: Characteristics of aerosol black carbon mass concentration over the high altitude location in the central Himalayas from multi-year observations, Atmos. Res., 96, 510-521, 2010.

Egger, J., Bajracharya, S., Egger, U., Heinrich, R., Reuder, J., Shakya, P., Wendt, H., and Wirth, V.: Diurnal winds in the Himalayan Kali Gandaki Valley. Part I: Observations, Mon. Weather Rev., 128, 1106-1122, 2000.

Engling, G. and Galencser, A.: Atmospheric brown clouds: from local air pollution to climate change, Elements, 6, 223-228, 2010.

Fadnavis, S., Semeniuk, K., Pozzoli, L., Schultz, M. G., Ghude, S. D., Das, S., and Kakatkar, R.: Transport of aerosols into the UTLS and their impact on the Asian monsoon region as seen in a global model simulation, Atmos. Chem. Phys., 13, 8771-8786, https://doi.org/10.5194/acp-13-8771-2013, 2013.

Fischer, E., Pszenny, A., Keene, W., Maben, J., Smith, A., Stohl, A., and Talbot, R.: Nitric acid phase partitioning and cycling in the New England coastal atmosphere, J. Geophys. Res., 111, D23S09, https://doi.org/10.1029/2006JD007328, 2006.

Gautam, R., Hsu, N. C., Tsay, S. C., Lau, K. M., Holben, B., Bell, S., Smirnov, A., Li, C., Hansell, R., Ji, Q., Payra, S., Aryal, D., Kayastha, R., and Kim, K. M.: Accumulation of aerosols over the Indo-Gangetic plains and southern slopes of the Himalayas: distribution, properties and radiative effects during the 2009 pre-monsoon season, Atmos. Chem. Phys., 11, 1284112863, https://doi.org/10.5194/acp-11-12841-2011, 2011.

Gustafsson, O., Kruså, M., Zencak, Z., Sheesley, R. J., Granat, L., Engström, E., Praveen, P. S., Rao, P. S., Leck, C., and Rodhe, H.: Brown clouds over South Asia: biomass or fossil fuel combustion?, Science, 323, 495-498, 2009.

Henne, S., Furger, M., Nyeki, S., Steinbacher, M., Neininger, B., de Wekker, S. F. J., Dommen, J., Spichtinger, N., Stohl, A., and Prévôt, A. S. H.: Quantification of topographic venting of boundary layer air to the free troposphere, Atmos. Chem. Phys., 4, 497509, https://doi.org/10.5194/acp-4-497-2004, 2004.

Hyvärinen, A. P., Lihavainen, H., Komppula, M., Sharma, V. P., Kerminen, V. M., Panwar, T. S., and Viisanen, Y.: Continuous measurements of optical properties of atmospheric aerosols in Mukteshwar, Northern India, J. Geophys. Res., 114, D08207, https://doi.org/10.1029/2008JD011489, 2009.

Hyvärinen, A.-P., Vakkari, V., Laakso, L., Hooda, R. K., Sharma, V. P., Panwar, T. S., Beukes, J. P., van Zyl, P. G., Josipovic, M., Garland, R. M., Andreae, M. O., Pöschl, U., and Petzold, A.: Correction for a measurement artifact of the Multi-Angle Absorption Photometer (MAAP) at high black carbon mass concentration levels, Atmos. Meas. Tech., 6, 81-90, https://doi.org/10.5194/amt-6-81-2013, 2013.

Jacobson, M. Z.: Strong radiative heating due to the mixing state of black carbon in atmospheric aerosols, Nature, 409, 695-697, 2001.

Janssen, N. A., Hoek, G., Simic-Lawson, M., Fischer, P., van Bree, L., ten Brink, H., Keuken, M., Atkinson, R. W., Anderson, H. R., Brunekreef, B., and Cassee, F. R.: Black carbon as an additional indicator of the adverse health effects of airborne par- ticles compared with $\mathrm{PM}_{10}$ and $\mathrm{PM}_{2.5}$, Environ. Health Persp., 119, 1691-1698, 2011.

Kang, S., Xu, Y., You, Q., Flugel, W.-A., Pepin, N., and Yao, T.: Review of climate and cryospheric change in the Tibetan Plateau, Environ. Res. Lett., 5, 015101, https://doi.org/10.1088/17489326/5/1/015101, 2010.

Kaufman, Y. J., Hobbs, P. V., Kirchhoff, V. W. J. H., Artaxo, P., Remer, L. A., Holben, B. N., King, M. D., Ward, D. E., Prins, E. M., Longo, K. M., Mattos, L. F., Nobre, C. A., Spinhirne, J. D., Ji, Q., Thompson, A. M., Gleason, J. F., Christopher, S. A., and Tsay, S. C.: Smoke, clouds, and radiation - Brazil (SCAR-B) experiment, J. Geophys. Res., 103, 31783-31808, 1998.

Kaufman, Y. J., Tanré, D., and Boucher, O.: A satellite view of aerosols in the climate system, Nature, 419, 215-223, 2002.

Komppula, M., Lihavainen, H., Hyvärinen, A.-P., Kerminen, V.M., Panwar, T. S., Sharma, V. P., and Viisanen, Y.: Physical properties of aerosol particles at a Himalayan background site in India, J. Geophys. Res., 114, D12202, https://doi.org/10.1029/2008JD011007, 2009.

Kopacz, M., Mauzerall, D. L., Wang, J., Leibensperger, E. M., Henze, D. K., and Singh, K.: Origin and radiative forcing of black carbon transported to the Himalayas and Tibetan Plateau, Atmos. Chem. Phys., 11, 2837-2852, https://doi.org/10.5194/acp-11-2837-2011, 2011.

Krupnick, A. J., Harrington, W., and Ostro, B.: Ambient ozone and acute health effects: evidence from daily data, J. Environ. Econ. Manage., 18, 1-18, 1990.

Lau, K. M., Kim, M. K., and Kim, K. M.: Asian summer monsoon anomalies induced by aerosol direct forcing: the role of the Tibetan Plateau, Clim. Dynam., 26, 855-864, 2006.

Lawrence, M. G. and Lelieveld, J.: Atmospheric pollutant outflow from southern Asia: a review, Atmos. Chem. Phys., 10, 11017 11096, https://doi.org/10.5194/acp-10-11017-2010, 2010.

Lee, K., Hur, S. D., Hou, S., Hong, S., Qin, X., Ren, J., Liu, Y., Rosman, K. J. R., Barbante, C., and Boutron, C. F.: Atmospheric pollution of trace elements in the remote high-altitude atmosphere in Central Asia as recorded in snow from Mt. Qomolangma (Everest) of the Himalayas, Sci. Total Environ., 404, 171-181, 2008.

Li, C., Bosch, C., Kang, S., Andersson, A., Chen, P., Zhang, Q., Cong, Z., Chen, B., Qin, D., and Gustafsson, Ö.: Sources of black carbon to the Himalayan-Tibetan Plateau glaciers, Nat. Commun., 7, 12574, https://doi.org/10.1038/ncomms12574, 2016.

Lu, Z., Zhang, Q., and Streets, D. G.: Sulfur dioxide and primary carbonaceous aerosol emissions in China and India, 1996-2010, Atmos. Chem. Phys., 11, 9839-9864, https://doi.org/10.5194/acp-11-9839-2011, 2011.

Lüthi, Z. L., Škerlak, B., Kim, S.-W., Lauer, A., Mues, A., Rupakheti, M., and Kang, S.: Atmospheric brown clouds reach the Tibetan Plateau by crossing the Himalayas, Atmos. Chem. Phys., 15, 6007-6021, https://doi.org/10.5194/acp-156007-2015, 2015.

Ma, J., Chen, Y., Wang, W., Yan, P., Liu, H., Yang, S., Hu, Z., and Lelieveld, J.: Strong air pollution causes widespread haze-clouds over China, J. Geophys. Res., 115, D18204, https://doi.org/10.1029/2009JD013065, 2010.

Marinoni, A., Cristofanelli, P., Laj, P., Duchi., R., Putero, D., Calzolari, F., Landi, T. C., Vuillermoz, E., Maione, M., and Bonasoni, P.: High black carbon and ozone concentrations during pollution transport in the Himalayas: five years of continuous ob- 
servations at NCO-P global GAW station, J. Environ. Sci., 25, 1618-1625, 2013.

Menon, S., Hansen, J., Nazarenko, L., and Yunfeng, L.: Climate effects of black carbon aerosols in aerosols in China and India, Science, 297, 2250-2253, 2002.

Pant, P., Hegde, P., Dumka, U. C., Sagar, R., Satheesh, S. K., Krishna Moorthy, K., Saha, A., and Srivastava, M. K.: Aerosol characteristics at high-altitude location in central Himalayas: optical properties and radiatuve forcing, J. Geophys. Res., 111, D17206, https://doi.org/10.1029/2005JD006768, 2006.

Piketh, S. J., Annegarn, H. J., and Tyson, P. D.: Lower tropospheric aerosol loadings over South Africa: the relative contribution of aeolian dust, industrial emissions, and biomass burning, J. Geophys. Res., 104, 1597-1607, 1999.

Putero, D., Cristofanelli, P., Marinoni, A., Adhikary, B., Duchi, R., Shrestha, S. D., Verza, G. P., Landi, T. C., Calzolari, F., Busetto, M., Agrillo, G., Biancofiore, F., Di Carlo, P., Panday, A. K., Rupakheti, M., and Bonasoni, P.: Seasonal variation of ozone and black carbon observed at Paknajol, an urban site in the Kathmandu Valley, Nepal, Atmos. Chem. Phys., 15, 13957-13971, https://doi.org/10.5194/acp-15-13957-2015, 2015.

Qian, Y., Flanner, M. G., Leung, L. R., and Wang, W.: Sensitivity studies on the impacts of Tibetan Plateau snowpack pollution on the Asian hydrological cycle and monsoon climate, Atmos. Chem. Phys., 11, 1929-1948, https://doi.org/10.5194/acp11-1929-2011, 2011.

Ram, K., Sarin, M. M., and Hegde, P.: Long-term record of aerosol optical properties and chemical composition from a highaltitude site (Manora Peak) in Central Himalaya, Atmos. Chem. Phys., 10, 11791-11803, https://doi.org/10.5194/acp-10-117912010, 2010.

Ramachandran, S. and Rajesh, T. A.: Black carbon aerosol mass concentrations over Ahmedabad, an urban location in western India: comparison with urban sites in Asia, Europe, Canada, and the United States, J. Geophys. Res., 112, D06211, https://doi.org/10.1029/2006JD007488, 2007.

Ramanathan, V. and Carmichael, G.: Global and regional climate changes due to black carbon, Nat. Geosci., 1, 221-227, 2008.

Ramanathan, V. and Crutzen, P. J.: New directions: atmospheric brown "clouds", Atmos. Environ., 37, 4033-4035, 2003.

Ramanathan, V., Chung, C., Kim, D., Bettge, T., Buja, L., Kiehl, J. T., Washington, W. M., Fu, Q., Sikka, D. R., and Wild, M.: Atmospheric brown clouds: impacts on South Asian climate and hydrological cycle, P. Natl. Acad. Sci. USA, 102, 5326-5333, 2005.

Ramanathan, V., Ramana, V. M., Roberts, G., Kim, D., Corrigan, C., Chung, C., and Winker, D.: Warming trends in Asia amplified by brown cloud solar absorption, Nature, 448, 575-578, 2007a.

Ramanathan, V., Li, F., Ramana, M. V., Praveen, P. S., Kim, D., Corrigan, C. E., Nguyen, H., Stone, E. A., Schauer, J. J., Carmichael, G. R., Adhikary, B., and Yoon, S. C.: Atmospheric brown clouds: hemispherical and regional variations in longrange transport, absorption, and radiative forcing, J. Geophys. Res., 112, D22821, https://doi.org/10.1029/2006JD008124, $2007 b$.

Reiter, E. R. and Tang, M.: Plateau effects on diurnal circulation patterns, Mon. Weather Rev., 112, 638-651, 1984.
Royal Society: Ground-Level Ozone in the 21st Century: Future Trends, Impacts and Policy Implications, Science policy report 15/08, The Royal Society, London, 2008.

Sander, R., Keene, W, C., Pszenny, A, A, P., Arimoto, R., Ayers, G, P., Baboukas, E., Cainey, J, M., Crutzen, P, J., Duce, R, A., Hönninger, G., Huebert, B, J., Maenhaut, W., Mihalopoulos, N., Turekian, V, C., and Van Dingenen, R.: Inorganic bromine in the marine boundary layer: a critical review, Atmos. Chem. Phys., 3, 1301-1336, https://doi.org/10.5194/acp-3-1301-2003, 2003.

Sarangi, T., Naja, M., Ohja, N., Kumar, R., Lal, S., Venkataramani, S., Kumar, A., Sagar, R., and Chandola, H. C.: First simultaneous measurements of ozone, $\mathrm{CO}$ and $\mathrm{NO}_{y}$ at a high-altitude regional representative site in the central Himalayas, J. Geophys. Res., 119, 1592-1611, 2014.

Singh, R. P., Dey, S., Tripathi, S. N., Tare, V., and Holben, B.: Variability of aerosol parameters over Kanpur, northern India, J. Geophys. Res., 109, D23206, https://doi.org/10.1029/2004JD004966, 2004.

Srivastava, A. K., Singh, S., Pant, P., and Dumka, U. C.: Characteristics of black carbon over Delhi and Manora peak - a comparative study, Atmos. Sci. Lett., 13, 223-230, 2012.

Steinacker, R.: Area-height distribution of a valley and its relation to the valley wind, Beitr. Phys. Atmos., 57, 64-71, 1984.

Tripathi, S. N., Dey, S., Tare, V., and Satheesh, S. K.: Aerosol black carbon radiative forcing at an industrial city in northern India, Geophys. Res. Lett., 32, L08802, https://doi.org/10.1029/2005GL022515, 2005.

Tripathi, S. N., Srivastava, A. K., Dey, S., Satheesh, S. K., and Moorthy, K. K.: The vertical profile of atmospheric heating rate of black carbon aerosols at Kanpur in northern India, Atmos. Environ., 41, 6909-6915, 2007.

Ueno, K., Toyotsu, K., Bertolani, L., and Tartari, G.: Stepwise onset of monsoon weather observed in the Nepal Himalayas, Mon. Weather Rev., 136, 2507-2522, 2008.

Vasilyev, O. B., Contreras, A. L., Velazquez, A. M., Fabi, R. P., Ivlev, L. S., Kovalenko, A. P., Vasilyev, A. V., Jukov, V. M., and Welch, R. M.: Spectral optical properties of the polluted atmosphere of Mexico City (spring-summer 1992), J. Geophys. Res., 100, 26027-26044, 1995.

Weissmann, M., Braun, A. F. J., Gantner, A. L., Mayr, A. G. J., Rahm, A. S., and Reitebuch, A. O.: The Alpine Mountain-Plain Circulation: airborne Doppler Lidar measurements and numerical simulations, Mon. Weather Rev., 133, 3095-3109, 2005.

Whiteman, C. D. and Bian, X.: Use of radar profiler data to investigate large-scale thermally driven flows into the Rocky Mountains, Proc. Fourth Int. Symp. on Tropospheric Profiling: Needs and Technologies, Snowmass, CO, 1998.

Xu, C., Ma, Y. M., You, C., and Zhu, Z. K.: The regional distribution characteristics of aerosol optical depth over the Tibetan Plateau, Atmos. Chem. Phys., 15, 12065-12078, https://doi.org/10.5194/acp-15-12065-2015, 2015.

Zhang, R., Wang, H., Qian, Y., Rasch, P. J., Easter, R. C., Ma, P.L., Singh, B., Huang, J., and Fu, Q.: Quantifying sources, transport, deposition, and radiative forcing of black carbon over the Himalayas and Tibetan Plateau, Atmos. Chem. Phys., 15, 62056223, https://doi.org/10.5194/acp-15-6205-2015, 2015. 